\title{
LEGAL ANALYSIS AND TERMINOLOGY ${ }^{2}$
}

\author{
Arthur L. Corbin \\ Professor of Law, Yale University
}

Every student of the law must be equipped with certain fundamental concepts and with certain terms in which to express them. Let him read the federal Constitution or the opinion of any court or any legal treatise, or let him listen to the lecture of any law professor, and every sentence will be likely to bristle with rights and duties, powers, privileges, liabilities, and immunities. He will gradually realize also that these terms are frequently used loosely, each term often being used to express several distinct concepts, and he will find that our dictionaries merely record this wide and variable usage and aid little toward the clear expression essential to exact reasoning.

No doubt the beginner cannot be made to realize at once the disadvantages attendant upon variableness of terms and uncertainty of concept. But it is quite possible at the very outset to master a number of fundamental legal concepts and to acquire a single definite meaning for each of the terms used to express them. With such simple concepts and definite phraseology the student can more easily analyze a complex problem, arrive at a correct solution, and explain it clearly to others. He can thus be led to avoid much unnecessary obscurity and difficulty. As his experience increases he must test for himself the accuracy and usefulness of the analysis and terminology. The following definitions are offered, chiefly for the benefit of beginning students of the law, in order to assist in establishing an exact terminology and a definiteness and accuracy of mental concept. These definitions are in large part based upon the articles of Professor Wesley N. Hohfeld, referred to below.

I. FACT: This is a world of facts. Physical existence and physical relations are facts. Our mental processes are facts. The existence of any legal relation is a fact. All changes and variations are facts. Facts include acts and events.

II. ACr: An act is one of that class of facts manifest to the senses that consists of voluntary physical movements (muscular contractions that are willed) of human beings. A forbearance is a consciously willed absence of physical movement. Animals other than men can act or forbear, but they do not become parties to a legal relation.

III. Event: Any change in the existing totality of facts, including the acts of human beings.

\footnotetext{
${ }^{2}$ Prepared with the critical assistance of other members of the Yale Law Faculty.
} 
IV. Operative Fact: Any fact the existence or occurrence of which will cause new legal relations between persons. A clear distinction should always be observed between the physical phenomena and the legal relations consequent thereon. The former are in the world of the senses, the latter are intellectual conceptions. Operative facts have also been described as "investitive," "constitutive," "causal," and "dispositive." The "extinguishment" of a legal relation is necessarily the creation of a new one.

V. Evidential FAcT: Any fact the existence or occurrence of which tends to prove the existence of some other fact. For example, a footprint on the sand is.a fact from which we may infer the recent presence of a man.

Evidential facts may themselves be operative as well, but need not be. For example, if A strikes B this fact often creates a right to damages and the same time it is evidence (not conclusive) of an intent in A's mind.

VI. Material FAct: A fact is material when it is either operative or evidential.

VII. Physical Relation: A relation perceivable by the senses, between two physical objects. This would include relations of space, time, weight, color, density, and the like.

VIII. LEgal ReLATion: A law is a rule concerning human conduct, established by those agents of an organized society who have legislative power. ${ }^{2}$ When a rule of law has been reduced to words it is a statement of the legal effect of operative facts; i. e. it is a statement that certain facts will normally be followed by certain immediate or remote consequences in the form of action or non-action by the judicial and executive agents of society. Whenever any such operative facts exist the persons who will be affected by the stated consequences are said to have a legal relation each to the other. When we state that some particular legal relation exists we are impliedly asserting the existence of certain facts, and we are expressing our present mental concept of the societal consequences that will normally follow in the future. A statement that a legal relation exists between $\mathrm{A}$ and $\mathrm{B}$ is a prediction as to what society, acting through its courts or executive agents, will do or not do for one and against the other. ${ }^{3}$ If $A$ invades B's house, we are able to predict that the police will eject $A$, that a court will give judgment for damages, and that the sheriff will levy execution.

\footnotetext{
2 These agents may be a king, a council, a court, a legislature composed of a few representatives, or the entire mass of voters.

It may be equally important to be able to predict the conduct of other persons in purely private affairs or to predict other events, but this has nothing to do with law. E. g. Will a structure withstand a go-mile wind? Will John propose to Priscilla? At what price will shares sell next week? Will the barking dog bite? What will the weather be?
} 
We say that $B$ had a right that $A$ should not intrude and that $A$ had a duty to stay out. But if $B$ had invited $A$ to enter, we know that those results would not occur. In such case we say that $B$ had no right that $A$ should stay out and that $A$ had the privilege of entering.

The term "legal relation" should always be used with reference to two persons, neither more nor less. One does not have a legal relation to himself. Nor does one have $a$ legal relation with two others; he has separate legal relations with each. A so-called legal relation to the State or to a corporation may always be reduced to many legal relations with the individuals composing the State or the corporation, even though for convenient discussion they may be grouped. There can be no such thing as a legal relation between a person and a thing. The relation of $\mathrm{A}$ to his house is a physical relation; but $\mathrm{A}$ has many legal relations to other persons with respect to his house.

Furthermore, the legal relations of any two persons are frequently numerous and complex, and it is of great service to analyze them into their simplest forms. Such terms of the law as "contract," "trust," "property" and "marriage" do not represent a single legal relation; they describe and represent complex and variable aggregates of legal relations. For clear thinking and for just and correct decision it is necessary to analyze these complex concepts into their simpler and invariable elements.

What then are these simple elements? Before attempting any formal definitions, they may first be indicated in a popular way. Assuming that we wish to determine the legal relations of $A$ and $B$, we may ask ourselves the following questions:

(I) What may A (or B) do, without societal penalty assessed for the benefit of the other?

(2) What must A (or B) do, under threat of societal penalty assessed for the benefit of the other?

(3) What can A (or B) do, so as to change the existing legal relations of the other? (This has no reference to mere physical power.)

If we determine that $A$ may conduct himself in a certain way he has a privilege with respect to $\mathrm{B}$, and $\mathrm{B}$ has no-right that $\mathrm{A}$ shall not so conduct himself.

If we determine that $A$ must conduct himself in a certain manner he has a duty to $\mathrm{B}$, and $\mathrm{B}$ has a right against $\mathrm{A}$.

If we determine that by his own voluntary act $A$ can change $B$ 's legal relations with $A$ (or with $X$ ), $A$ has a legal power and $B$ has a liability.

If we determine that $A$ cannot by his own voluntary act change the legal relations of $\mathrm{B}$, then $\mathrm{A}$ has a disability and $\mathrm{B}$ has an immunity.

Having isolated these definite concepts and chosen these specific terms with which to express them-all being found in the actual 
decisions and usage of the courts - Professor Wesley N. Hohfeld ${ }^{4}$ then arranged them in the following pairs of opposites and correlatives:

\begin{tabular}{|c|c|c|c|c|}
\hline & 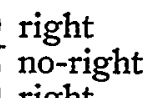 & $\begin{array}{l}\text { privilege } \\
\text { duty }\end{array}$ & $\begin{array}{l}\text { power } \\
\text { disability }\end{array}$ & \\
\hline Cors & $\begin{array}{l}\text { right } \\
\text { duty }\end{array}$ & $\begin{array}{l}\text { privilege } \\
\text { no-right }\end{array}$ & $\begin{array}{l}\text { power } \\
\text { liability }\end{array}$ & \\
\hline
\end{tabular}

Each pair of correlatives must always exist together; when some person (A) has one of the pair, another person (B) necessarily has the other. One of the terms expresses the relation of $A$ to $B$; the other term expresses the relation of $B$ to $A$.

No pair of opposites can exist together. That is, when a person has a right, he cannot have a no-right with respect to the same subject matter and the same person. When he has a privilege, he cannot have a duty.

The following grouping of terms may be useful:

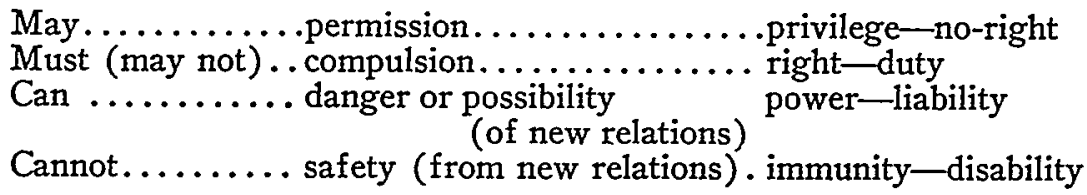

Observe that when we assert that some fact or group of facts will operate to create a particular legal relation we are stating a rule of law. The mere statement that a certain legal relation exists is a statement of fact. Thus: (a) A owes B \$100.-statement of fact. (b) C owns Blackacre-statement of fact. (c) An offer creates a power in the offeree-rule of law. (d) The delivery of a deed conveys title to land-rule of law. (e) The delivery of a release under seal discharges a debtor (creates privilege in place of duty) - rule of law.

'See, for example, Joy v. St. Louis (1890) I38 U. S. I, 7, 9, 36 and 38, II Sup. Ct. 243, where a contract and a deed are quoted as follows: "And also the said party of the first part hath conveyed, assigned, and transferred . . . all the right, title or interest of the party of the first part of, in or to the right of way, and of, in or to any and all other rights, privileges and franchises, powers and immunities, owned by or vested in or enjoyed by the party of the first part." And again "the parties of the second part are to enter upon and enjoy the right of way and all the rights, privileges, immunities, powers, improvements, and property belonging to or vested in" etc.

In the case of Indiana Harbor Belt R. Co. v. Green (Igrg, I11.) I24 N. E. 298, the court found it necessary to construe "An act concerning the rights, powers and duties of certain corporations therein mentioned, authorizing the sale and transfer of any railroad, or railroad and toll bridge, and other property, franchises, immunities, rights, powers and privileges connected therewith."

'A careful study should be made of Professor Hohfeld's articles entitled Some Fundamental Legal Conceptions as Applied in Judicial Reasoning (I913) 23 Yale Law Journal, I6 and (IgI7) 26 ibid., 7Io. Professor Hohfeld was professor of law in Yale University from IgI4 until his untimely death in October, I9I8. 
Rules of law, enabling us to determine the operative effect of facts, are not discovered by mere analysis; they are discovered rather by a study of history-by a knowledge of written statutes, of precedents, and of social mores. The terms and method of analysis here presented are merely to make possible a greater clearness of mental concept and a nicer accuracy of expression.

We may now proceed to the more formal definition of the eight named legal relations, and also of several varieties of rights.

(I) Right: A legal relation between two persons. The correlative of duty, and the opposite of no-right. An enforceable claim to performance (action or forbearance) by another. It is the legal relation of $A$ to $B$ when society commands action or forbearance by $B$ and will at the instance of $\mathrm{A}$ in some manner penalize disobedience.

A, knowing that he has a particular right, can answer this question, "What must another do for me?" (The court will aid me by using compulsion if he does not do it.)

Examples: (a) B owes A \$roo.

(b) B has contracted for a consideration to deliver goods to or do labor for $A$. In each case $A$ has a right and $B$ has a correlative duty.

(c) A has a right that $B$ shall not strike him, and $B$ has a duty not to strike.

(2) Duty: The correlative of the concept right, above defined, and the opposite of privilege. It is the legal relation of a person, $\mathrm{B}$, who is commanded by society to act or to forbear for the benefit of another person, A, either immediately or in the future, and who will be penalized by society for disobedience.

$\mathrm{B}$, knowing that he has a particular duty, can answer this question, "What must I do for another?" (A court will use compulsion against me if I do not do it.)

Examples: See examples under (I) above.

Rights and duties may be Primary or Secondary, Instant or Future, Conditional or Unconditional, In rem or In personam, Joint or Several.

(3) Privilege: The correlative of the legal concept no-right and the opposite of duty. The legal relation of $A$ to $B$ when $A$ (with respect to $B$ ) is free or at liberty to conduct himself in a certain matter as he pleases; when his conduct is not regulated for the benefit of $B$ by the command of society; and when he is not threatened with any penalty for disobedience, for the reason that society has made no command.

A, knowing that he has a particular privilege, can answer this question, "What may I do?" (A court will not prevent me or penalize me.)

Observe carefully that the concept privilege does not itself include a right to non-interference by another person, although such a privilege and such a right very commonly are found together. Being the 
opposite of duty, it is another name for no duty. If I am under no duty to $A, I$ am with respect to A privileged.

Examples: (a) A assaults $B$. This gives $B$ the legal privilege of striking back (commonly called the "right" of self-defence).

(b) $\mathrm{B}$ is sworn as a witness. He now has the privilege of saying words about another person that it was previously his legal duty not to say. What was previously slander is now a privileged statement.

(c) A neutral in war time has the privilege of shipping contraband to a belligerent. Other belligerents have no-right that he shall refrain, but they too are then privileged to seize the contraband. The neutral is privileged to run, when sighted, but if he disobeys a signal to heave to, the belligerent is then privileged to sink him.

(4) No-RIGHT: The correlative of privilege, and the opposite of right. The legal relation of a person (A) in whose behalf society commands nothing of another (B) A has no control over B. A, knowing that he has no-right against $B$, can answer this question, "What may another person (B) do ?" (A court will not prevent him or penalize him.)

Examples: A tells $B$ that he may walk across A's yard. This gives $B$ a privilege and terminates $A$ 's right that $B$ shall not so walk, thus creating a relation of no-right in $\mathrm{A}$. But $\mathrm{B}$ does not have a right, for $A$ is privileged to lock $B$ out. See also examples under (3) above.

(5) Power: The correlative of liability, and the opposite of disability (disability=no power). The legal relation of $A$ to $B$ when A's own voluntary act will cause new legal relations either between $B$ and $A$ or between $B$ and a third person.

A, knowing that he has a particular power, can answer this question, "What new legal relations can I create between B and myself or others?"

A sharp distinction must be drawn between legal power and physical power. Thus a person may have a legal power to make a will even though he is too weak physically to sign his name; i. e., he has the legal power but is physically unable to do the volitional act by which it is to be exercised.

Examples: (a) A's voluntary act of picking up a shell on the seashore creates as against $B$ a right of non-interference with possession. So $A$ has a power to create such a right against $B$. (This new right is a constituent part of that aggregate of legal relations called ownership, title, or property.)

(b) A having made an offer to B, the latter has the pozver to create contractual rights, etc., by accepting.

(c) X writes to A that the latter may sell X's land. A then has a power to make and accept offers. Distinguish sharply the following: (I) the physical acts of $\mathrm{X}$; (2) the material document sent to A; (3) the legal relation of power in A, a mere mental concept. 
(d) A has the legal power, by assaulting $B$, of creating a secondary right to damages in $\mathrm{B}$.

Observe that legal power is not always accompanied by legal privilege; there may be a duty not to use it.

(6) Lrability: The correlative of power, and the opposite of immunity. (Immunity=no liability.) The relation of A to B when A may be brought into new legal relations by the voluntary act of $B$. $A$ is liable to have new legal relations created for himself through the exercise by $B$ of B's power. The new relations may be with third persons, or with $B$, or with both; but the liability-power relation is between $A$ and $B$ only.

A, knowing that he has a certain liability, can answer this question, "What new legal relations can $B$ create between me and himself or others?"

Examples: (a) A having made an offer to B, A now has a liability that $B$ will create contractual relations by accepting (the exercise of B's power).

(b) A being the owner of Blackacre and having given to $B$ the power to convey to $\mathrm{X}, \mathrm{A}$ has a liability of being brought into property relations with $\mathrm{X}$. Likewise every third person has the same liability of being brought into property relations with $\mathrm{X}$. B's exercise of his power, his voluntary act of conveyance, will give $X$ rights against $A$ and also against all third persons, each of whom will come under correlative duties to $X$. These duties they cannot avoid; for previously to B's act of conveyance $B$ has power to create these new relations, and each third party has the liability to their creation. Such is the law of property. B's conveyance to X makes him the owner, creating between him and all other persons those innumerable relations of right, privilege, power, and immunity of which "property" or "ownership" consists. ${ }^{B}$

(c) B having given $\mathrm{A}$ a privilege to cross B's land, $\mathrm{A}$ has a liability to the extinguishment of his privilege by revocation, or in other words, to the creation of a duty not to cross.

Note carefully the distinction between liability and duty, inasmuch as one of the popular uses of this term is to describe the relation of duty. It is such double, triple, or quadruple meanings that make terms slippery, confuse thought, and cause erroneous and unjust decisions. Hence the necessity of adopting some one specific meaning, as is attempted here. A owes B \$100: the legal relation particularly in mind is a duty to pay. There may no doubt also be a liability to the creation of new legal relations by a judgment.

Observe that liabilities are not always disadvantageous to the possessor, although it is the disadvantageous ones with which we are most often concerned. The correlative power in another person may bc

- See definitions 9 and 19 , infra, indicating what property relations may be. 
only to create valuable rights, privileges, powers and immunities. Thus where A's debt to $B$ has been barred by the statute of limitations $B$ has a liability to the recreation of his right by a voluntary new promise by $A$ (the exercise of a power by $A$ ).

(7) Immunity: The correlative of disability (no power), and the opposite of liability (no immunity). The relation of $A$ to $B$ when $B$ has no legal power (has disability) to affect some one or more of the existing legal relations of $A$. As to that particular existing relation A has an immunity with respect.to $B$.

A, knowing that he has a certain immunity, can answer this question, "Which one of my existing legal relations is safe from alteration by B?"

Examples: (a) A owns Blackacre. His right that $B$ shall not enter cannot be extinguished by the voluntary act of $B$; so that with respect to $B, A$ has immunity. At the same time $A$ may have no such immunity with respect to $C$, for the latter may have been given the power to convey Blackacre to $B$ and thus extinguish $A$ 's right against $\mathrm{B}$.

(b) The Constitution declares that no state shall impair the obligation of a contract. With respect to state legislatures, therefore, a contractor has an immunity.

(c) If a citizen of Connecticut has no land, goods, or business in New York he has an immunity from taxation there. The State of New York has a disability (no power) to tax in such a case.

(8) Disability: The correlative of immunity, and the opposite of power. The relation of $A$ to $B$ when by no voluntary act of his own can A extinguish one (or more) of the existing legal relations of $B$.

A, knowing that he has a particular disability, can answer this question, "What existing legal relation of another person (B) is it impossible for me to extinguish?"

Examples: See the examples of immunity under (7) above, where B in the one case and the legislators in the other case have disabilities.

(9) Right in Rem: A right possessed by A against $B$ when it happens to be one of innumerable similar rights possessed by $A$ against all (or nearly all) other members of organized society, each one of whom is under a correlative duty to $A$ (these innumerable duties being likewise similar). Professor Hohfeld has suggested as a substitute the term "multital right."

Examples: (a) A owns Blackacre. He has a right against $B$ that $B$ shall not trespass, and similar rights against $C, D, X, Y$, etc. But if $A$ has told $M$ that he may walk across, he has no such right against $M$.

(b) A has a right that $B$ shall not strike him. He has similar rights

\footnotetext{
${ }^{7}$ See particularly and at length his article in (Igr7) 26 YALE LAw JouRNaL, 7 ro.
} 
against $C, D, X, Y$, etc. But if $A$ is $M$ 's minor son, and has disobeyed, he has no such right against $M$.

(c) A patentee has a right that B shall not manufacture or sell, and similar rights against $\mathrm{C}, \mathrm{D}, \mathrm{X}, \mathrm{Y}$, etc. But he may have licensed $\mathrm{M}$ to manufacture and sell.

Observe that a right in rem is not a right in a thing or a right against a thing. Legal relations are relations between persons.

Observe also that a right in rem is not a right against the world or against all other persons.

The term "right in rem" is commonly used to include other legal relations in rem, viz., relations of privilege, pozer, and immunity. This must be avoided.

(I0) Right in Personam: A right possessed by A against B, unaccompanied by similar rights against all (or nearly all) others. It may be accompanied by similar rights against certain specific other persons. If it is totally unaccompanied, Professor Hohfeld calls it a "unital" right; and if accompanied by similar rights against several specific persons, he calls it a "paucital" right."

Examples: (a) A holds B's promissory note for $\$ 100$. A's right against B is unaccompanied or "unital."

(b) $\mathrm{B}$ strikes $\mathrm{A}$ without justification. A has a right to damages from $B$, a secondary right, unaccompanied or "unital."

(c) A holds the joint or joint and several promissory note of $\mathrm{B}, \mathrm{C}$, and $D$, for $\$ 100$. A's right against $B$ is not in rem; it is a "paucital" right. He has exactly similar rights against $C$ and $D$.

(II) PRIMARy RIGHT: A right resulting from some operative fact that was not itself a violation of some precedent right. Primary rights may be either in rem or in personam, either multital or paucital or unital.

(I2) SECONDARY Right: A right resulting from some operative fact that was a violation of some precedent right. So-called "remedial" rights are always secondary. Secondary rights are always in personam, paucital or unital.

(13) Multital Right: See Right in rem, No. 9.

(x4) Paucital Right: See Rrght in personam, No. xo.

(I5) Unital Right: See Right in personam, No. Io.

Observe that privileges, powers, immunities, duties, no-rights, disabilities, and liabilities, as well as rights; may all conceivably be multital, paucital, or unital.

(x6) Instant And Future Rights: The right of A may be that $B$ shall act in a certain way at once, instantly, or that $B$ shall so act at some future date. If it is the latter, we say that $A$ has a right to future action by $B$. Such a right is not called a conditional right,

\footnotetext{
See (19I7) 26 ibid., 7 ro.
} 
even though the arrival of the date is a necessary operative fact, for the reason that it is certain to occur.

Example: A holds B's promissory note for $\$$ Ioo payable on June I next. On June I A's right to future payment becomes an instant right.

(I7) Conditional Right: This is a right to a future performance that does not become instant by the mere arrival of a date, but becomes so only upon the occurrence of some uncertain operative fact. The creation of an instant right often requires the occurrence of several operative facts. If some of these have occurred but one has not, that one is a condition precedent to the existence of an instant right. Prior to the occurrence of this one fact we often describe the legal relations as a conditional right and a conditional duty.

Examples: (a) A pays B $\$$ roo and $B$ promises to deliver a bale of goods on their arrival aboard the ship Peerless. This is a unilateral contract, and $\mathrm{A}$ has a conditional right.

(b) For a premium of $\$ 50$ paid, an insurer agrees to pay $A$ \$10,000 if a house burns down.

(c) A agrees to work for B for $\$$ roo a week payable weekly. Here the completion of a week's work is a condition precedent to A's instant right. Meanwhile $\mathrm{A}$ has a conditional right; he may also be said to have a power, in case the condition is mere voluntary action by himself. The term unconditional right includes all instant rights and also all rights to future performance that depend on no fact other than the passage of time. ${ }^{9}$

There is no need to discuss here such terms as "divine right" and "absolute right." They have no proper place in a system of human justice.

(I8) JoINT RIGHT: A right may be a "joint" right either because there are (a) several obligees or (b) several obligors.

(a) If $X$ gives his promissory note to $A$ and $B$ jointly, legal relations are created between $A$ and $X$ and between $B$ and $X$ (as well as between $A$ and $B$ ). A has a right that $X$ shall pay either $A$ or $B$, and $B$ has an exactly similar right against $X$. The character of these relations is not in the least affected by the rule that A's secondary right to $a$ judgment is conditional upon B's joining as plaintiff.

Observe that $A$ 's right against $X$ is not a "paucital" right; it is unital, inasmuch as he has no similar right against any other person. Observe also that the relations between $A$ and $X$ are distinct from those between $B$ and $X$. $A$ and $B$ are independent persons. They are not "one," even in "the eye of the law."

(b) If $X$ and $Y$ give their joint promissory note to $A$, he has two rights, one against $X$ and an exactly similar one against $Y$, that the full sum shall be paid at maturity. In this case each of A's rights is

- See discussion of Conditions in the Law of Contract (rgig) $28 \mathrm{Y}_{\mathrm{ALE}} \mathrm{L}_{\mathrm{A}}$ Journal, 739; Anson on Contract (Corbin's ed. rgIg) secs. 355-400. 
a "paucital" right. Here, too, A's secondary right to a judgment is conditional upon his joining both as co-defendants; or, at least either $\mathrm{X}$ or $\mathrm{Y}$ when sued alone would have the power of depriving $\mathrm{A}$ of his right to a judgment by pleading in abatement.

In the above illustration it should be noted that the right to payment is quite different from the right to judgment. The first is against a party; the second is against the court.

(19) Legal Interest: The aggregate of the legal relations of a person with respect to some specific physical object or the physical relations of specific objects.

Examples: (a) A owns Blackacre. He has a legal interest, consisting of various rights, privileges, powers, and immunities. Here his interest is "property." (The term property is often used to denote physical objects. Such use should be carefully distinguished.)

(b) A has contracted with $B$ to employ $B$ and to pay salary. A has here an interest consisting of contract rights, powers, etc., against $\mathrm{B}$, and certain multital rights, powers, etc., against all other persons. ${ }^{10}$ Because of A's multital rights, powers, etc., his interest is here also sometimes described as "property."

(c) A has a legal interest in the physical safety of his wife, multital rights that she shall not be harmed, her affections alienated, etc.

Distinguish sharply between "legal interest" and the physical objects themselves with respect to which and for the enjoyment of which the legal relations are created.

Distinguish also between "legal interest" and that sort of "interest" that consists merely of an emotion or a state of mind.

Distinguish further the kind of "interest" that is a return or compensation for money loaned; the rate fixed by contract or by law is sometimes referred to as "legal interest."

${ }^{10}$ Lumley v. Gye (1853, Q. B.) 2 El. \& B1. 216. 